\title{
IMPLEMENTASI PENANAMAN NILAI KARAKTER MELALUI PEMBELAJARAN SIRAH NABAWIYAH
}

\author{
Arrosikh \\ Universitas Islam Negeri Mataram \\ Email: aufarrosih@gmail.com
}

\begin{abstract}
Abstrak: Penelitian ini bertujuan untuk mengetahui; implementasi penanaman nilai karakter melalui pembelajaran sirah nabawiyah, upaya guru dalam implementasi penanaman nilai-nilai karakter melalui pembelajaran sirah nabawiyah, kendala dalam pelaksanaan implementasi penanaman nilai karakter melalui pembelajaran sirah nabawiyah dikelas tinggi SDIT Anak Sholeh. Penelitian ini dilakukan dengan menggunakan pendekatan kualitatif. Pendekatan kualitatif adalah metode yang digunakan untuk meneliti pada kondisi obyek yang alamiah. Teknik yang digunakan dalam penelitian ini adalah wawancara, observasi, dan dokumentasi. Adapun proses analisis data yang dilakukan peneliti dalam penelitian ini yaitu dengan mengambil dan menerapkan pola interaktif yang dikembangkan Miles dan Huberman ynag terdiri dari reduksi data, penyajian data, kesimpulan dan verivikasi. Hasil penelitian menunjukkan bahwa dengan pembelajaran di dalam kelas dan pengimplementasian sirah nabawiyah melalui pembbiasaan kegiatan sekolah, diantaranya adalah budaya sekolah, sholat berjamaah, tahsin Al-qur'an, Tahfiz Al-quran, Ramadhan ceria, market day, dan qurban peduli. Beberapa kegiatan tersebut dilaksanakan sebagai bentuk implementasi nilai karakter sirah nabawiyah kepada siswa. Kendala yang dihadapi adalah materi yang terbilang monoton, kurangnya Refrensi bahan ajar yang berkaitan dengan sirah nabawiyah dan sirah sahabiyah, kurangnya guru dalam memahami penilaian sikap serta tenaga pengajar yang terbatas.
\end{abstract}

Kata Kunci: Nilai Karakter, Sirah Nabawiyah

Title: Implementation of Character V alue Planting Through the Learning of Nabawiyah Sirah

\begin{abstract}
This study aims to determine; implementation of character value planting through the learning of nabawiyah Sirah, teacher's efforts in implementing character values planting through learning nabawiyab Sirah, obstacles in implementing the implementation of character value planting through the learning of nabawiyah Sirah in the bigh grade of SDIT pious child. This research was conducted using a qualitative approach. A qualitative approach is a method used to examine the condition of natural objects. The techniques used in this study are interviews, observation, and documentation. The data analysis process carried out by researchers in this study is by taking and applying an interactive pattern developed by Miles and Huberman which consists of data reduction, data presentation, conclusions, and verification. The results showed that by learning in the classroom and implementing Nabawiyah Sirah through the customization of school activities, including school culture, prayer in congregation, Tabsin Al-Qur'an, Tabfiz. Al-Qur'an, cheerful Ramadan, market day, and caring qurban. Some of these activities are carried out as a form of implementation of Sirah Nabawiyah character values to students. Constraints faced are fairly monotonic material, lack of reference to teaching materials related to Nabawiyah Sirah and sahabiyah Sirah, lack of teachers in understanding attitude assessment, and limited teaching staff.
\end{abstract}

Keywords: Character Value, Nabawiyah Sirah. 


\section{PENDAHULUAN}

Sebagaimana diketahui bahwa pendidikan merupakan suatu masalah yang sangat penting dalam kehidupan, karena tanpa pendidikan kehidupan manusia tidak akan terarah. Tolak ukur kemajuan suatu bangsa dalam pandangan global yaitu apabila tingkat sumber daya manusianya tinggi. Dalam arti luas pendidikan baik formal maupun informal meliputi segala hal yang memperluas pengetahuan manusia tentang dirinya sendiri dan tentang dunia tempat mereka hidup. ${ }^{1}$ Pendidikan dipandang sebagai salah satu aspek yang memiliki peranan pokok dalam membentuk generasi mendatang. Menurut Arifin dalam buku Pendidikan Islam berpendapat bahwa pendidikan sebagai usaha membentuk pribadi manusia harus melalui proses yang panjang, dengan resultat (hasil) yang tidak dapat diketahui dengan segera, berbeda dengan keinginan pembuatnya. ${ }^{2}$ Jadi dengan pendidikan diharapkan dapat menghasilkan manusia yang berkualitas dan bertanggung jawab serta mampu mengantisipasi masa depan pendidikan dalam maknanya yang luas, senantiasa mendorong, menyertai dan membimbing perubahan perkembangan kehidupan manusia sesuai

Rumusan tujuan pendidikan nasional yang dituangkan dalam pasal 3 UU No. 20 tahun 2003 tentang sistem pendidikan nasionl (SISDIKNAS), adalah untuk berkembangnya potensi peserta didik agar menjadi manusia yang beriman dan bertaqwa kepada Tuhan Yang Maha Esa, berkhlak mulia, sehat dan bertanggung jawab. Rumusan ini menekankan terbentuknya karakter manusia yang spesifik menjadi tujuan akhirnya.

Membicarakan karakter merupakan hal yang penting dan mendasar. Karakter adalah mustika hidup yang membedakan manusia dengan binatang. Orang-orang yang berkarakter kuat dan baik secara individual maupun sosial ialah mereka yang memiliki akhlak, moral, budi pekerti yang baik, begitu urgennya karakter maka institusi pendidikan memiliki tanggung jawab untuk menanamkannya melalui proses pembelajaran. ${ }^{3}$ Upaya membangun karakter dan bangsa (nation and character building) merupakan tugas bersama yang tak akan pernah selesai. Pendidikan karakter saat ini bukan saja merupakan hal yang penting bagi lembaga pendidikan, tetapi menjadi kebutuhan yang harus diberikan kepada peserta didik, karena kebutuhan bangsa ini bukan hanya mengantarkan dan mencetak peserta didik cerdas dalam nalar, tetapi juga cerdas dalam moral. Mencetak anak yang berprestasi secara nalar memang tidak mudah, tetapi mencetak anak bermoral jauh lebih sulit dilakukan, apalagi dengan perkembangan teknologi canggih yang semakin cepat dan pesat, yang tentunya akan berdampak terhadap perkembangan anak. Kini Kementerian pendidikan nasional menyusun sebuah grand design

\footnotetext{
1 Abdullah, Studi Akblak Dalam Perspektif Al-Qur'an (Jakarta: Ahmaz, 2007), h. 21

${ }^{2}$ Nur Uhbiyati, Ilmu Pendidikan Islam (Pandu: Pustaka Setia, 2005), h. 25

${ }^{3}$ Zubaedi, Desain pendidikan karakter, konsepsi dan aplikasinya dalam lembaga pendidikan (Bengkulu: Kencana Prenada Media Group, 2011). h. 1
} 
pendidikan karakter untuk menyiapkan generasi yang berwatak dan bermartabat baik dimasa datang. ${ }^{4}$

Komitmen nasional tentang perlunya pendidikan karakter secara imperatif tertuang dalam undang-undang No 20 tahun 2003 tentang Sisdiknas dalam pasal 3 UU tersebut dinyatakan bahwa "pendidikan nasional berfungsi mengembangkan kemampuan dan membentuk watak serta peradaban bangsa yang bermartabat dalam rangka mencerdaskan kehidupan bangsa, bertujuan untuk berkembangnya potensi peserta didik agar menjadi manusia yang beriman dan bertaqwa kepada tuhan Yang Maha Esa, berakhlak mulia, sehat, berilmu, cakap, kreatif, mandiri, dan menjadi warga negara yang demokratis serta bertanggung jawab." Dilihat dari tujuan pendidikan nasional, titik beratnya memang pada pengembangan potensi yang bermuara pada karakter peserta didik, hal itu tercermin dalam penekanan pada aspek-aspek berakhlak mulia, cakap, kreatif, mandiri, demokratis, dan bertanggung jawab. Semua aspek itu sejatinya merupakan bagian dari karakter manusia. ${ }^{5}$

Pelaksanaan pendidikan karakter bangsa dapat dilakukan secara formal, non formal maupun informal. Dalam lingkungan formal, (Satuan pendidikan) pendidikan dapat dilakukan secara formal maupun nonformal. Secara formal, yaitu dengan implementasi pendidikan karakter dalam setiap mata pelajaran, dan berbagai metode pembelajaran, sedangakan secara nonformal dapat dilakukan dengan pembentukan budaya sekolah (school culture). ${ }^{6}$

Dalam pelaksanaan pendidikan karakter di sekolah semua komponen harus dilibatkan termasuk komponen pendidik itu sendiri, yaitu isi kurikulum, proses pembelajaran, penilaian, kualitas hubungan, penanganan atau pengelolaan mata pelajaran, pengelolaan sekolah, pelaksanaan aktivitas atau kegiatan kurikuler, pemberdayaan sarana prasarana, pembiayaan dan etos kerja seluruh warga di lingkungan sekolah. Keberhasilan pendidikan karakter tidak hanya ditentukan oleh besarnya peranan pendidik dalam memberikan pengajaran atau bimbingan tetapi juga ditentukan oleh lingkungan sosial dalam memberikan situasi yang kondusif dalam pengembangan karakter, nilai-nilai tersebut tidak hanya cukup disampaikan konseptual, tetapi dibutuhkan latihan yang terus menerus dan diterapkan dalam kehidupan sehari-hari.

Dalam pelaksanaan pendidikan karakter tersebut dapat dilaksanakan sesuai dengan kemampuan lembaga pendidikan, agar tujuan pendidikan karakter tersebut dapat berjalan dengan baik maka lembaga pendidikan berupaya untuk menciptakan lingkungan pendidikan yang keselurahan aspek dan kegiatan dalam lembaga pendidikan tersebut mendukung terlaksananya aspek pendidikan karakter, lembaga pendidikan bisa melaksanakan kegiatan-

4 Zainal Aqib, pendidikan karakter disekolah, membangun karakter dan kepribadian anak (Bandung: Yrama widya, 2012). h. 23

5 Ibid., h. 24

6 Zainal Aqib, pendidikan karakter, h. 104 
kegiatan pembelajaran dengan inovasi lembaga pendidikan itu sendiri agar tujuan pelaksanaan pendidikan karakter tersebut dapat tercapai dengan baik, salah satunya dengan menambahkan pembelajaran sirah nabawiyah dalam jam pelajaran siswa.

Pembelajaran Sirah nabawiyah merupakan hal yang penting untuk diajarkan kepada siswa sebagai proses pembentukan karakter, dengan mempelajari sirah Rasulullah SAW yang begitu agung dan sarat dengan nilai-nilai moral maka akan menumbuhkan kecintaan terhadap Rasulullah SAW dan jika telah tertanam rasa cinta maka tentunya akan timbul rasa ingin meneladani Rasulullah SAW. Nabi muhammad SAW adalah contoh terbaik dalam akhlak mulia, yang merupakan hasil pendidikan islam, dengan belajar dari akhlak beliau, dapat diasumsikan bahwa karakter bangsa ini bisa menuju kepada kesempurnaan. Dalam penelitian ini menekankan terbentuknya karakter peserta didik seperti yang dicontohkan Rasulullah SAW seperti karakter jujur, disiplin, tanggung jawab, sopan santun dan tolong menolong. Yang merupakan dasar dari pengembangan karakter dan akhlak mulia yang diajarkan oleh Rasulullah SAW.

Dalam sejarah Islam sekitar 1400 tahun yang lalu, Muhammad SAW sebagai nabi terakhir dalam ajaran islam, juga menegaskan bahwa misi utamanya dalam mendidik manusia adalah untuk menyempurnakan akhlak dan mengupayakan pembentukan karakter yang baik (good caracter). ${ }^{7}$ Dialah Rasulullah, Nabi Muhammad SAW yang menjadi tokoh inspirasi dalam banyak hal dan multi-ahli. Allah swt berfirman dalam surat al-Ahzab ayat 21;

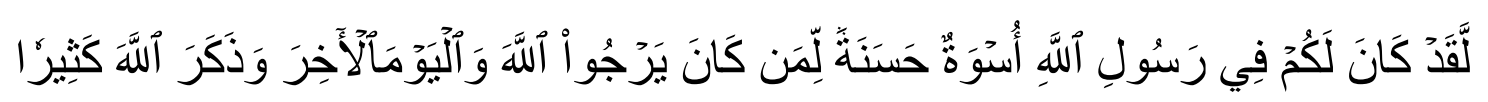

"Sesunggubnya telah ada pada (diri) rasulullah itu suri teladan yang baik bagimu (yaitu) bagi orang yang mengharap (rahmat) Allah dan (kedatangan) hari kiamat dan dia banyak menyebut Allah."8

Melalui Nabi SAW lah, ayat-ayat dan isi kandungan al- Quran disampaikan kepada umat manusia. Proses penyampaian ayat dan petunjuk serta suri tauladan yang diperlihatkan oleh nabi itu lah yang disebut dengan pendidikan, sehingga karakter dan suri tauladan Rasulullah SAW dapat dijadikan sebagai materi Pendidikan Karakter yang paling baik dan paling sempurna. Nabi Muhammad SAW merupakan suri teladan yang baik secara keseluruhan. Karakternya dapat dijadikan sebagai bahan kurikulum pendidikan karakter yang selama ini kurang mengena. Melalui pembelajaran Sirah Nabawiyah, nilai karakter beliau dapat dipelajari dengan memahami beberapa peristiwa yang dialami rasulullah SAW yang sesuai dengan kehidupan saat ini.

Mengingat pentingnya pendidikan karakter serta penerapannya, Sekolah Dasar Islam Terpadu (SDIT) Anak Soleh Mataram mempunyai misi dalam menerapkan pendidikan

7 Abdul majid dkk, pendidikan karakter perspektif islam (bandung: PT. Remaja rosdakarya,2011), h. 2 h. 420

${ }^{8}$ Departemen Agama RI,Al-quran dan Terjemahannya, ( Bandung : Yayasan Penterjemah Al-qur'an, 2008), 
karakter sebagai proses perkembangan ke arah manusia kaffah dan diharapkan penanaman nilai pendidikan karakter lebih kondusif, tetapi masih banyak siswa yang belum dapat mencapai misi yang dicanangkan, karena masih banyak ditemui kendala dalam penerapannya.

Berdasarkan hasil observasi awal bahwa pendidikan karakter secara umumnya sudah mulai diterapkan di SDIT Anak Soleh mataram, dari berbagai kegiatan outdoor. ${ }^{9}$ kemudian dalam proses pembelajaran sirah nabawiyah, guru melaksanakan proses pembelajaran dengan berbagai metode, seperti story taler, kelompok diskusi, penugasan dan berbagai metode yang lain yang sudah disesuaikan oleh guru mata pelajaran yang bersangkutan, dalam pembelajaran sirah nabawiyah SDIT Anak Sholeh Mataram juga memiliki buku pedoman pendidikan karakter (buku penghubung) yang dijadikan acuan untuk melihat indikator perubahan perilaku dan karakter peserta didik. Dalam belajar sirah nabawiyah nilai karakter yang kembangkan di SDIT Anak Sholeh Mataram terfokus pada beberapa karakter yang disesuaikan dengan jenjang kelas diantaranya yaitu, karakter disiplin, jujur, tanggung jawab, sopan santun, dan tolong menolong. hal ini dapat dilihat dari proses pembelajaran yang berlangsung maupun kegiatan-kegiatan diluar jam pelajaran. Walaupun demikian tidak semuanya berjalan sesuai dengan harapan dan banyak hambatan-hambatan yang dihadapi dalam proses penanaman nilai karakter yang kaitanya dengan pelajaran sirah nabawiyah yang salah satunya adalah masih minimnya buku-buku pelajaran yang berkaitan dengan sirah nabawiyah sehingga meyulitkan guru untuk memberikan materi dengan maksimal. ${ }^{10}$ Penelitian ini penting untuk dilaksanakan karena peneliti beranggapan bahwa pendidikan karakter menjadi solusi terbaik untuk membentuk karakter peserta didik sesuai yang diharapkan.

\section{METODE PENELITIAN}

Penelitian ini dilakukan dengan menggunakan pendekatan kualitatif. Pendekatan kualitatif adalah metode yang digunakan untuk meneliti pada kondisi obyek yang alamiah, (sebagai lawannya adalah eksperimen) dimana peneliti adalah sebagai instrumen kunci, teknik pengumpulan data dilakukan secara trigulansi (gabungan), analisis data bersifat induktif, dan hasil penelitian kualitatif lebih menekankan makna dari pada generalisasi. ${ }^{11}$ Dalam pendekatan kualitatif ini penulis menggunakan teknik deskriptif, yang mana teknik ini penulis tidak hanya mengumpulkan dan menyusun data dan informasi tetapi juga menganalisa dan menginterpretasinya. Penelitian deskriptif adalah penelitian yang tidak dimaksudkan untuk menguji hipotesis tertentu, tetapi hanya untuk menggambarkan "apa adanya” tentang sesuatu

9 Observasi, tanggal 23 Maret 2018

10 Wawancara, dengan WAKA Kurikulum Ustazah Aisyah, SD IT Anak Sholeh Mataram, tanggal 10 April 2018

11 Sugiyono, Memahami Penelitian Kualitatif (Bandung: ALFABETA, 2009), h. 9 
variabel, gejala atau keadaan. ${ }^{12}$ Dalam artian ini, penelitian deskriptif adalah akumulasi data dasar dengan cara deskriptif dengan tidak mencari atau menerangkan hubungan, hipotesa atau pendapat makna. ${ }^{13}$

Kehadiran peneliti dalam penelitian ini berperan sebagai instrumen kunci atau alat penelitian yang secara langsung terlibat dalam kehidupan subyek yang sudah ditentukan peneliti. Kehadiran peneliti merupakan hal yang mutlak karena seluruh rangkaian dari rencana penelitian akan dapat teraplikasi dengan baik. Dengan instrumen penelitiannya adalah peneliti sebagai instrumen. Pengumpulan data merupakan bagian terpenting dalam suatu penelitian. Bahkan suatu keharusan bagi seorang peneliti untuk memperoleh informasi dan data yang dibutuhkan dalam penelitian. Untuk mendapatkan data dan informasi dalam penelitian ini, digunakan beberapa teknik yang relevan sesuai dengan penelitian kualitatif. Teknik yang digunakan dalam penelitian ini adalah wawancara, observasi, dan dokumentasi.

Analisis data dalam penelitian ini dilakukan saat pengumpulan data berlangsung. Pada saat wawancara peneliti sudah melakukan analisis terhadap jawaban yang di wawancarai, bila jawaban yang diwawancarai setelah dianalisis terasa belum memuaskan, maka peneliti akan melanjutkan pertanyaan lagi, sampai tahap tertentu diperoleh data yang dianggap kredibel. Analisis data yang digunakan dalam penelitian ini adalah analisis induktif. Artinya, analisis data induktif adalah berfikir yang berangkat dari fakta-fakta atau hal-hal yang bersifat khusus atau peristiwa kongkrit, kemudian ditarik suatu kesimpulan, analisis induktif ini lebih khusus peneliti gunakan untuk menganalisis data hasil wawancara guna mendapatkan suatu kesimpulan yang utama dari beberapa informasi atau hasil wawancara yang di dapatkan dari informan atau responden, yang kemudian diuraikan dan dibahas dari hal-hal yang bersifat khusus kemudian di tarik kesimpulan. Adapun proses analisis data yang dilakukan peneliti dalam penelitian ini yaitu dengan mengambil dan menerapkan pola interaktif yang dikembangkan Miles dan Huberman yang mana terdapat 3 tahapan dalam kegiatan analisis data yaitu: Reduksi Data, Penyajian Data, Kesimpulan dan Verivikasi. Dengan keabsahan menggunakan Triangulasi dan perpanjangan penelitian.

\section{TEMUAN DAN PEMBAHASAN}

Implementasi Penanaman Nilai Karakter Melalui Pembelajaran Sirah Nabawiyah di Kelas Tinggi SDIT Anak Sholeh Mataram Kec. Sekarbela Kota Mataram Tahun Pelajaran 2019/2020.

1. Pembelajaran Sirah Nabawiyah

Penyampaian materi sirah nabawiyah dikelas tinggi SDIT Anak sholeh mataram dilakukan melalui pembelajaran didalam kelas dengan perangkat-perangkat pembelajaran

\footnotetext{
${ }^{12}$ Suharsimi, Manajemen Penelitian (Jakarta: Rineka Cipta), h. 234

${ }^{13}$ Suryabrata, Metodologi Penelitian (Jakarta: Rineka Cipta, 2004), h. 76
} 
(RPP dan Silabus) dan pengimplenetasian pembelajaran tersebut melalui kegiatan keseharian siswa selama di lingkungan sekolah. Peserta didik kelas V SDIT Anak sholeh Mataram, mereka mendapatkan materi sirah nabawiyah dan nilai-nilai karakter yang terkandung dalam pembelajaran tersebut yang bisa dijadikan contoh dalam kehidupan sehari-hari, penguatan konsep yang diberikan oleh guru berupa masalah-masalah yang sering muncul dan berkaitan dengan kehidupan keseharian siswa.

Berkaitan dengan pembelajaran sirah nabawiyah, siswa kelas V SDIT Anak Sholeh Mataram yang mendapatkan materi pelajaran tersebut, guru selalu mengingatkan kepada siswa agar membiasakan diri menjadikan rasulullah dan sahabatnya sebagai teladan dalam akhlak, yang secara umum SDIT Anak Sholeh Mataram mengimplementasikan empat sifat rasulullah yakni sidiq, amanah, tabhlig, dan fathanah kedalam pendidikan karakter dan budaya sekolah, sehingga pendidikan karakter yang dicanangkan pihak sekolah dapat diukut dan dievaluasi pelaksanaannya.

Penanaman nilai karakter dalam bentuk pelaksanaan proses pembelajaran dilakukan dengan pengenalan nilai-nilai karakter dan penanaman nilai karakter dalam diri siswa dalam kehidupan sehari-hari melalui proses pembelajaran didalam kelas maupun diluar kelas. Pengimplementasian karakter pada siswa melalui pembelajaran sirah nabawiyah yang akan berperan penting dalam meningkatkan aktifitas belajar siswa dan mendorong kesadarannya untuk belajar secara jujur, disiplin dan bertanggung jawab. Hal ini sesuai dengan apa yang disampaikan oleh kepala sekolah SDIT Anak Sholeh Mataram,

"tentunya kami dari pihak sekolah selalu berharap yang terbaik kepada siswa-siswi disini, oleh karena itu pihak sekolah berusaha merancang perencanaan kurikulum pembelajaran dan perangkat pembelajaran lainnya dengan maksimal dan melibatkan seluruh komponen pendidik, dengan harapan memberikan dampak positif terhadap siswa, dalam hal perilaku maupun dalam hal prestasi akademik"14.

Hasil wawancara peneliti dengan guru kelas V SDIT Anak Sholeh Mataram, Siti Aisyah, S.pd menyatakan bahwa implementasi pendidikan karakter yang dilakukan melalui proses pembelajaran dilakukan didalam kelas dengan menyiapkan perangkat pembelajaran (RPP dan Silabus) berkarakter, perangkat yang berkarakter maksudnya adalah nilai-nilai karakter yang ditanamkan kepada siswa, hal tersebut dilakukan agar proses pembelajaran berjalan optimal.

2. Imlementasi penanaman nilai karakter di SDIT Anak Sholeh mataram

Implementasi nilai-nilai pendidikan karakter di SDIT Anak Sholeh Mataram berupa pembinaan karakter siswa dalam keseharian, pada dasarnya di SDIT Anak Sholeh Mataram melakukan evaluasi pembelajaran sirah nabawiyah tidak hanya dilakuakan

14 Wawancara, Wahidah, SE. dilalaksanakan tanggal 9 Desember 2019 
dengan ujian-ujian tertulis saja melainkan juga dievaluasi dalam praktik pengamalan keseharian siswa di lingkungan sekolah.

Berdasarkan hasil wawancara dan observasi yang peneliti lakukan, terdapat beberapa nilai karakter yang sudah mampu diimplementasikan oleh peserta didik maupun guru-guru SDIT Anak Sholeh Mataram. Implementasi nilai pendidikan karakter dalam pembelajaran sirah nabawiyah di SDIT Anak Sholeh Mataram dilaksanakan melalui beberapa kegiatan sekolah diantaranya:

a. Budaya sekolah

Budaya sekolah yang dilaksanakan di SDIT Anak Sholeh Mataram adalah berupaya untuk membiasakan dan membentuk karakter siswa, dalam hal ini ada beberapa nilai yang dijadikan budaya sekolah di SDIT Anak Sholeh Mataram, diantaranya: Budaya 3 S (senyum, Salam, sapa), disiplin, ramah, sopan santun dan tata karma, bertanggung jawab, jujur, menjaga kebersihan diri dan lingkungan, mengerjakan tugas rumah yang diberikan guru, memiliki kegemaran membaca, bekerjasama

b. Sholat Berjamaah

Salah satu upaya implementasi pendidikan karakter di SDIT Anak Sholeh Mataram adalah dengan adanya program Sholat Duha' dan sholat Dzuhur berjmaah, hal ini dilakuakn agar membiasakan siswa lebih taat dan disiplin waktu dalam melaksanakan sholat.

c. Tahsin Al-Qur'an

Tahsin Al-qur'an dilaksanakan di SDIT Anak Sholeh Mataram, sebagai sarana evaluasi kemapuan membaca Al-qur'an oleh siswa, dilaksanakan setiap hari Jum'at, biasanya guru kelas membuat kelompok kecil antar siswa dan guru menyimak bacaan mereka.

d. Tahfiz Al-Qur'an Juz 29-30

Salah satu program yang dibuat oleh SDIT Anak sholeh mataram untuk menumbuhkan kecintaan siswa terhadap Al-qur'an adalah program tahfiz qur'an, dengan harapan dapat menjadikan siswa-siswi SDIT anak sholeh mataram menjadi peserta didik yang tidak hanya pandai secara intelektual semata tapi juga mempunyai jiwa qurani.

e. Market Day

Market day adalah program di SDIT Anak Sholeh mataram yang dilaksanakan setiap 1x dalam bulan untuk melatih jiwa wirausaha siswa.

f. Ramadhan Ceria

Ramadhan ceria adalah kegiatan yang diadakan di bulan Ramadan oleh SDIT Anak sholeh Mataram untuk melatih anak dalam memaknai bulan ramadhan, 
harapannya dengan adanya kegiatan ini para murid akan selalu merindukan bulan yang penuh rahmat, yakni bulan ramadhan, kegiatan dalam program ramadhan ceria ini seperti pesantren kilat, pengajian, tahsin, hafalan surat-surat pendek, belajar tata cara sholat tarawih, pemutaran film islami dan lomba da'i cilik.

g. Qurban Peduli

Adalah kegiatan yang dilaksanakan di SDIT Anak Sholeh mataram sebagai sarana media pembelajaran bagi para siswa dengan menitiberatkan pada pemahaman keutamaan pengorbanan dan peduli kepada sesama.

Beberapa kegiatan diatas memang menjadi kegiatan yang diprogramkan rutin oleh pihak sekolah guna melatih dan membiasakan karakter-karakter islami kepada para siswa, tentunya masih banyak kegiatan yang lain yang secara umum dilaksanakan di SDIT Anak sholeh, seperti renang, kunjungan ilmiah, eskul memanah dan robotika. Namun peneliti berfokus pada beberapa program sekolah yang memang relefan dengan pengimplementasian nilai karakter pada siswa.

Dalam proses implementasi Pendidikan karakter melalui pembelajaran sirah nabawiyah dikelas tinggi SDIT Anak Sholeh Mataranm yang merupakan suatu proses pendidikan secara holistis yang menghubungkan dimensi moral dengan ranah sosial dalam kehidupan peserta didik sebagai pondasi bagi terbentuknya generasi yang berkualitas yang mampu hidup mandiri dan memiliki prinsip suatu kebenaran yang dapat dipertanggungjawabkan. Pihak sekolah SDIT Anak Sholeh Mataram menyusun penilaian ketercapain karakter peserta didik dengan pedoman pelaksanaan pendidikan karakter yang dicanagkan oleh pemerintah (2011) adalah:

a. Religius, sikap dan perilaku yang patuh dalam melaksanakan ajaran agama yang dianutnya, toleran terhadap pelaksanaan ibadah agama lain, hidup rukun dengan pemeluk agama lain

b. Jujur, perilaku yang didasarkan pada upaya menjadikan dirinya sebagai orang yang selalu dapat dipercaya dalam perkataan, tindakan dan pekerjaan

c. Toleransi, sikap dan tindakan yang menghargai perbedaan agama, suku, etnis, pendapat, sikap dan tindakan orang lain yang berbeda dengan dirinya

d. Disiplin, tindakan yang menunjukkan perilaku tertib dan patuh pada berbagai ketentuan dan peraturan

e. Kerja keras, perilaku yang menunjukkan upaya yang sungguh-sungguh dalam mengatasi berbagai hambatan guna menyelesaikan tugas

f. Kreatif, berpikir dan melakukan sesuatu untuk menghasilkan cara atau hasil baru dari sesuatu yang telah dimiliki 
g. Mandiri, sikap dan perilaku yang tidak mudah tergantung pada orang lain dalam menyelesaikan tugas

h. Demokratis, cara berfikir, cara bersikap, bertindak yang menilai sama hak dan kewajiban dirinya dan orang lain

i. Rasa ingin tahu, sikap dan tindakan yang selalu berupaya untuk mengetahui lebih mendalam dan meluas dari sesuatu yang dipelajarinya, dilihat dan didengar

j. Semangat kebangsaan, cara berpikir, bertindak berwawasan yang menempatkan kepentingan bangsa dan negara di atas kepentingan diri dan kelompoknya

k. Cinta tanah air, cara berfikir, bersikap dan berbuat yang menunjukkan kesetiaan kepedulian dan penghargaan yang tinggi terhadap bahasa, lingkungan fisik, sosial budaya ekonomi dan politik bangsa

1. Menghargai prestasi, sikap dan tindakan dirinya untuk menghasilkan sesuatu yang berguna bagi masyarakat dan mengakui serta menghormati keberhasilan orang lain

m. Bersahabat/komunikatif, tindakan yang memperlihatkan rasa senang berbicara, bergaul dan bekerjasama dengan orang lain

n. Cinta damai, sikap dan tindakan yang mendorong dirinya untuk menghasilkan sesuatu yang berguna bagi masyarakat ,mengakui serta menghormati keberhasilan orang lain

o. Gemar membaca, kebiasaan menyediakan waktu untuk membaca berbagai bacaan yang memberikan kebajikan bagi dirinya

p. Peduli lingkungan, sikap dan tindakan yang selalu berupaya mencegah kerusakan pada lingkungan alam disekitarnya

q. Peduli sosial, sikap dan tindakan yang selalu ingin memberi bantuan pada orang lain dan masyarakat yang membutuhkan

r. Tanggung jawab, sikap dan perilaku seseorang untuk melaksanakan tugas dan kewajibannya yang seharusnya ia lakukan terhadap diri, masyarakat, lingkungan sekitarnnya

\section{Kendala-kendala yang Dihadapi dalam Implementasi Penanaman Nilai Karakter Melalui Pembelajaran Sirah Nabawiah di Kelas Tinggi SDIT Anak Sholeh Mataram Tahun Ajaran 2019/2020.}

Perjalanan sebuah proses pendidikan dan pembinaan, tentu akan ditemukan faktorfaktor penghambat, di samping faktor pendukung tentunya. Faktor pendukung, tentu berdampak positif karena akan sangat membantu dalam mencapai tujuan proses pembinaan. Sedangkan faktor penghambat adalah faktor yang sedapat mungkin harus diatasi dan dicarikan solusi agar tidak mengganggu proses pendidikan dan pembinaan. Begitu juga dalam pelaksanaan implementasi penanaman nilai karakter Melalui pembelajaran Sirah Nabawiah 
dikelas Tinggi SDIT Anak sholeh Mataram. Berikut adalah hasil observasi dan wawancara Peneliti dengan salah satu siswa Kelas V SDIT Anak Sholeh Mataram, Raihan Akbar yang menyatakan;

"Saya tidak terlalu suka pelajaran sejarah, cepat bosan dan bikin ngantuk, lebih seru kalau belajar diluar kelas atau dengan nonton film kartun islami"15

Selain kendala-kendala dalam pembelajaran sirah nabawiyah seperti hasil wawancara dengan siswa tadi juga ada beberapa Kendala dalam pelaksanaan implementasi penanaman nilai karakter Melalui pembelajaran Sirah Nabawiah dikelas Tinggi SDIT Anak sholeh Mataram yang peneliti temukan dilapangan adalah sebagai berikut:

1. Kendala dalam pembelajaran sirah nabawiyah di kelas

Kendala dari pembelajaran sirah nabawiyah dikelas tinggi SDIT Anak Sholeh Mataram adalah sebagai berikut

a. Materi yang terbilang monoton

b. Siswa yang tidak bersemangat dalam belajar

c. Siswa yang tidak focus dan lebih banyak bermain saat pelajaran berlangsung

d. Kurangnya buku referensi dan bahan ajar yang berkaitan dengan sirah nabawiyah dan sirah sahabiyah

e. Banyak aspek penilaian karakter yang harus dinilai oleh guru sehingga menyita waktu

f. kurangnya refrensi bahan ajar yang berkaitan dengan sirah nabawiyah dan sirah sahabiyah,

g. Kurangnya persiapan sarana yakni jumlah LCD Projector yang ada di SDIT Anak Sholeh Mataram.

2. Kendala dalam implementasi nilai karakter di SDIT Anak Sholeh Mataram

Kendala yang dihadapi guru dan pihak sekolah dalam implenetasi penananman nilai karakter disekolah adalah sebagai berikut,:

a. Dalam pelaksanaan budaya sekolah, guru kesulitan melakukan penilaian sikap terhadap peserta didik karena melihat apa yang memang Nampak saja.

b. Sholat berjamaah, dalam pelaksanaan sholat berjamaah guru kesulitan mengontrol siswa, jumlah MCK dan tempat whudu yang terbatas sehingga siswa yang belum whudu kadang bermain-main dan masbuk saat sholat berjamaah.

c. Tahsin al-qur'an, kendala yang dihadapi saat pelaksanaan tahsin adalah kemampuan siswa yang berbeda dari satu dengan yang lain, sehingga ada yang sudah lancar dan fasih dalam membaca Al-Qur'an dan ada juga yang masih terbata-bata.

15 Wawancara, Raihan Akbar, Siswa kelas V SDIT Anak Sholeh Mataram, tanggal 9 Desember 2019 
d. Tahfiz al-qur'an, kendala yang dihadapi dalam kegiatan tahfiz qur'an adalah kemampuan siswa dalam menghafal yang berbeda-beda, ada yang kemampuan hafalannya cepat dan ada juga yang lambat.

e. Market day, dalam kegiatan market day yang sering menjadi kendala adalah, siswa yang tidak terbiasa dalam berjualan, dan malu-malu dalam menawarkan jualannya kepada temannya.

f. Ramadhan ceria, dalam kegiatan ini guru terkendala dengan kepanitiaan yang sedikit sehingga kesulitan untuk mengontrol beberapa kegiatan secara bersamaan.

g. Qurban peduli, dalam kegiatan qurban peduli guru terkendala dengan kesulitan mengkoordinir siswa yang saat mengikuti kegiatan saat berqurban dan proses pembagian daging kurban kepada masyarakat sekitar lingkungan sekolah.

Apa yang telah diuraikan di atas, menjadi penghambat (kendala-kendala) dalam implementasi penanaman nilai karakter melalui pembelajaran sirah nabawiyah dikelas tinggi SDIT anak sholeh Mataram.

\section{Upaya Guru Mengatasi Kendala-kendala yang Dihadapi dalam Implementasi Penanaman Nilai Karakter Melalui Pembelajaran Sirah Nabawiyah Dikelas Tinggi SDIT Anak Sholeh Mataram, Kec. Sekarbela Kota Mataram Tahun Ajaran 2019/2020.}

Berdasarkan hasil wawancara peneliti dengan wakil kepala sekolah bidang kurikulum, terkait upaya apa yang sudah dilakukan untuk mengatasi kendala dalam implementasi penanaman nilai karakter, waka kurikulum SDIT Anak Sholeh Mataram menyatakan

"setiap kegiatan sekolah yang kami programkan, tentunya tidak semua bisa kami laksanakan dengan maksimal karna beberapa keterbatasan kami baik itu dari saranaprasarana maupun tenaga kependidikan kami disekolah yang masih terbatas untuk membekup banyak kegiatan siswa, namun kami disekolah terutama pihak yayasan maupun kepala sekolah selaku pemangku kebijakan selalu mengadakan rapat evaluasi jika terdapat kendala dalam pelaksanaan kegiatan sekolah yang sudah diprogramkan, apabila kendala yang dihadapi berkaitan dengan kebutuhan belajar didalam kelas tentu kami akan berkordinasi dengan sarana dan prasarana untuk menyediakan apa yang menjadi kebutuhan guru dalam belajar dikelas ${ }^{16}$.

Hal tersebut juga seperti yang disampaikan oleh guru kelas V SDIT Anak Sholeh mataram dalam upaya mengatasi kendala-kendala yang dihadapi dalam implementasi penanaman nilai karakter melalui pembelajaran sirah nabawiyah dikelas tinggi SD IT Anak Sholeh Mataram. ${ }^{17}$ Dalam mengatasi kendala dalam pembelajaran sirah nabawiyah guru menyusun perencanaan pembelajaran dengan materi yang berbeda-beda setiap pertemuan sehingga tidak terlalu monoton mengulang-ulang satu pokok bahasan saja dalam setiap

16 Wawancara, Siti Aisyah, S.pd. tanggal 5 Desember 2019
17 Wawancara, Ikah Farikah, SE. tanggal 9 Desember 2019 
pembelajaran sirah nabawiyah, pihak sekolah bekerja sama dengan penerbit buku untuk menyediakan buku atau bahan ajar yang lain yang berkaitan dengan sirah nabawiyah, pihak sekolah menambah pengadaan LCD, Projektor dan sarana prasarana lain yang dapat menujang pelaksanaan pembelajaran sirah nabawiyah. Sedangkan upaya yang dilakukan dalam mengatasi kendala dalam implementasi penanaman nilai karakter melalui;

1. Budaya sekolah, guru membuat standar penilaian sikap yang dapat dijadikan acuan dalam melakukan proses penilaian karakter terhadap siswa.

2. Sholat berjamaah, pihak sekolah menambah sarana prasarana tempat whudu agar siswa lama antri menunggu giliran whudu dan meminta guru setiap kelas untuk mengawasi siswa.

3. Tahsin al-qu'an, agar memudahkan guru dalam pelaksanaan tahsin, agar lebih focus kepada siswa yang masih belum lancar membaca al-qur'an dan siswa yang lebih lancar membaca agar tahsin saling menyimak bacaan dengan teman yang lain yang sudah lancar membaca.

4. Tahfiz Qur'an, guru membuat jadwal khusus untuk menyimak setoran hafalan siswa diluar jadwal yang sudah ditentukan sekolah agar tidak terlalu banyak menyita waktu.

5. Market day, dalam kegiatan ini guru mendampingi siswa yang masih malu-malu dalam mengikuti kegiatan market agar siswa tersebut menjadi terbiasa.

6. Ramadan ceria, sekolah melibatkan siswa dalam kepanitiaan kegiatan walaupun dalam hal-hal yang sederhana sebagai sarana pembelajaran bagi siswa.

7. Qurban peduli, dalam hal ini pihak sekolah melibatkan tokoh masyarakat dan orang tua siswa untuk berpartisipasi dalam pelaksanaan qurban peduli sehingga masyarakat sekitar juga diberdayakan dan siswa juga terkoordinir dengan baik ketika mengikuti kegiatan qurban peduli.

\section{SIMPULAN}

Dari hasil paparan dan temuan seperti yang peneliti uraikan maka diatas dapat disimpulkan bahwa: Pertama, pembelajaran Sirah Nabawiayah dikelas tinggi SDIT Anak Sholeh Mataram sudah dilaksanakan dengan cukup efektif, dengan pembelajaran di dalam kelas dan pengimplementasian sirah nabawiyah melalui pembiasan kegiatan sekolah, diantaranya adalah budaya sekolah, sholat berjamaah, tahsin Al-qur'an, Tahfiz Al-quran, Ramadhan ceria, market day, dan qurban peduli. Beberapa kegiatan tersebut dilaksanakan sebagai bentuk implementasi nilai karakter sirah nabawiyah kepada siswa. Kedua, kendala dalam pembelajaran sirah nabawiyah adalah materi yang terbilang monoton, kurangnya Refrensi bahan ajar yang berkaitan dengan sirah nabawiyah dan sirah sahabiyah, kurangnya julmah LCD Projector yang ada di SDIT Anak Sholeh Mataram, dan penilaian karakter yang cukup luas sehingga memerlukan banyak waktu bagi guru. Sedangkan kendala dalam 
implementasi nilai karakter melalui pembelajaran sirah nabawiyah di SDIT Anak Sholeh Mataram adalah: Guru kesulitan dalam melakukan penilaian sikap, guru kesulitan dalam mengontrol siswa, dalam pelaksanaan tahsin dan tahfiz guru kesulitan dalam mengidentifikasi kemampuan membaca al-qur'an siswa yang berbeda-beda, guru kesulitan dalam menumbuhkan semangat siswa berwirausaha, pihak sekolah terkendala dengan tenaga pengajar yang masih sedikit sehingga kesulitan untuk memantau siswa disetiap kegiatan sekolah.

Ketiga, upaya dalam mengatasi kendala dalam pembelajaran sirah nabawiyah adalah dengan cara guru menyusun perencanaan pembelajaran dengan materi yang berbeda-beda setiap pertemuan sehingga tidak terlalu monoton mengulang-ulang satu pokok bahasan saja dalam setiap pembelajaran sirah nabawiyah, pihak sekolah bekerja sama dengan penerbit buku untuk menyediakan buku atau bahan ajar yang lain yang berkaitan dengan sirah nabawiyah, pihak sekolah menambah pengadaan LCD, Projektor dan sarana prasarana lain yang dapat menujang pelaksanaan pembelajaran sirah nabawiyah. Sedangkan upaya mengatasi kendala dalam implemntasi penanaman nilai karakter adalah dengan cara; budaya sekolah, guru membuat standar penilaian sikap yang dapat dijadikan acuan dalam melakukan proses penilaian karakter terhadap siswa, sholat berjamaah, pihak sekolah menambah sarana prasarana tempat whudu agar siswa lama antri menunggu giliran whudu dan meminta guru setiap kelas untuk mengawasi siswa. Tahsin al-qu'an, agar memudahkan guru dalam pelaksanaan tahsin, agar lebih focus kepada siswa yang masih belum lancar membaca alqur'an dan siswa yang lebih lancar membaca agar tahsin saling menyimak bacaan dengan teman yang lain yang sudah lancar membaca. Tahfiz Qur'an, guru membuat jadwal khusus untuk menyimak setoran hafalan siswa diluar jadwal yang sudah ditentukan sekolah agar tidak terlalu banyak menyita waktu. Market day, dalam kegiatan ini guru mendampingi siswa yang masih malu-malu dalam mengikuti kegiatan market agar siswa tersebut menjadi terbiasa. Ramadan ceria, sekolah melibatkan siswa dalam kepanitiaan kegiatan walaupun dalam hal-hal yang sederhana sebagai sarana pembelajaran bagi siswa. Qurban peduli, dalam hal ini pihak sekolah melibatkan tokoh masyarakat dan orang tua siswa untuk berpartisipasi dalam pelaksanaan qurban peduli sehingga masyarakat sekitar juga diberdayakan dan siswa juga terkoordinir dengan baik ketika mengikuti kegiatan qurban peduli.

\section{DAFTAR PUSTAKA}

Abdullah. Studi Akhlak Dalam Perspektif Al-Qur'an. Jakarta: Ahmaz: 2007.

Adisusilo, S. Pembelajaran Nilai Karakter. Jakarta: PT. Raja Grafindo Persada, 2013.

Al-Mubarakfuri, S. S. Perjalan Hidup Rasul yang Agung Muhammad SAW: Dari Kelabiran Hingga Detik-Detik Terakhir.Jakarta: Darul Haq, 2005. 
Anshori, N. S.Pendidikan Karakter Nabi Muhammad SAW Dalam Buku Sirah Nabawiyah Terjemahan Kitab Ar-Rachiiqu Al-Makhtuum Karya Syeikh Shafiyurrahman AlMubarakfury. Skeripsi, Universitas Muhammadiyah Surakarta, Surakarta, 2013.

Aqib, Z. pendidikan karakter disekolah: membangun karakter dan kepribadian anak. Bandung: Yrama widya, 2012.

Ariyani. Implemetasi pendidikan karakter pada mata pelajaran IPS kelas V di SDN 2 Meninting tahun pelajaran 2014/2015. Skripsi, IAIN Mataram, Mataram, 2015.

Asmani, J. M. Buku Panduan Internalisasi Pendidikan Karakter di Sekolah. Jogjakarta: Diva Prees, 2011.

Departemen Pendidikan Nasional. Kamus Besar Bahasa Indonesia Pusat Bahasa: Edisi Keempat. Jakarta: PT. Gramedia Pustaka Utama, 2008.

Fitry, A. Z. Pendidikan Karakter Berbasis Nilai dan Etika di Sekolah.Jogjakarta: AR RUZZ Media, 2012.

Gunawan, H. Pendidikan Karakter Konsep dan Implementasi.Bandung: Alfabeta, 2012.

Hasanah, H. Implementasi Pendidikan Karakter dalam pembelajaran IPS Terpadu kelas VIII di MTs AL-Ikhlashiyah Perampuan Lombok Barat tahun ajaran 2014/2015. Skripsi, IAIN Mataram, Mataram, 2015.

Kadir, A. Dasar-Dasar Pendidikan. Jakarta: Kencana Prenada Media Group, 2012.

Majid, A. pendidikan karakter perspektif islam . Bandung: PT. Remaja rosdakarya, 2011.

Muslich, M. Pendidikan Karakter Menjawab Tantangan Krisis Multidimensional.Jakarta: Bumi Aksara, 2011.

Najib M, Manajement Masjid Sekolah Sebagai Laboratorium Pendidikan Karakter konsep dan implementasinya. Yogyakarta: Gava Media, 2015.

Nurpaizah, N.Implementasi nilai pendidikan karakter peduli lingkungan pada mata pelajaran IPS terpadu kelas VIII di SMPN 2 Kopang tahun pelajaran 2014/2015. Skripsi, IAIN Mataram, Mataram, 2016.

Riduwan. Belajar Mudah Penelitian: Untuk Guru-Karyawan dan Peneliti Pemula.Bandung: ALFABETA, 2013.

Saptono. Dimensi-Dimensi Pendidikan Karakter: Wawasan, Strategi dan Langkah Praktis. Salatiga: ESENSI Erlangga Group, 2011.

Sugiyono. Metode Penelitian Pendidikan: Pendekatan Kuantitatif, Kualitatif, dan R\&D. Bandung: ALFABETA, 2015.

Sutikno, M. S. Belajar dan Pembelajaran: Upaya Kreatif Dalam Mewujudkan Pembelajaran yang Berhasil. Lombok: HOLISTIKA 2013. 
Uhbiyati N. Ilmu Pendidikan Islam. Pandu: Pustaka Setia, 2005.

Yaumi, M. Pembelajaran Berbasis Multiple Intelegences. Jakarta: PT. Dian Rakyat, 2012.

Yaumi, M.Pendidikan Karakter Landasan, Pilar \& Implementasi.Jakarta: KENCANA, 2014.

Zubaedi. Desain pendidikan karakter: konsepsi dan aplikasinya dalam lembaga pendidikan. Bengkulu: Kencana Prenada Media Group, 2011. 